\title{
Insider Trading Around Convertible Security Calls
}

Jefferey D. Gramlich, University of Hawaii, Honolulu

Eric L. Mais, (Email: mais@cba.hawaii.edu), University of Hawaii, Honolulu

\begin{abstract}
This study examines the nature of insider trading of common stock around conversion-forcing calls of convertible securities. Managers of call firms significantly increase their frequency of stock sales after call announcements. Also after the call, substantially fewer call firms are classified as net buyers and a significantly greater number of call firms are classified as net sellers. This evidence suggests that managers alter their trading behavior as though calls are associated with negative information about their firms' prospects.
\end{abstract}

\section{Introduction}

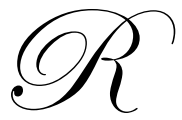

ecent research detects significant abnormal insider trading behavior around many types of firmspecific changes in asset and financial structure. For example, abnormal insider trading has been found to occur around equity issues (Karpoff and Lee 1991), stock repurchases (Lee, Mikkelson and Partch 1992), takeovers (Seyhun 1990), dividend changes (John and Lang 1991), asset sales (Hirshey and Zaima 1989), earnings forecasts (Penman 1982), and bankruptcy (Seyhun and Bradley 1997). This body of research suggests that insiders increase (decrease) their holdings around favorable (unfavorable) announcements of firm-specific information. We extend the research on insider trading behavior by examining the trading activity of insiders around conversion-forcing calls of convertible bonds and convertible preferred stocks. In particular, this study provides additional evidence regarding the nature of information (if any) revealed by calls of convertible securities.

Mikkelson (1981), Mais, Moore and Rogers (1989) and others find that announcements of in-the-money convertible security calls are associated with negative equity valuation effects. ${ }^{1}$ Explanations offered for this adverse stock price effect can be divided into two broad categories of hypotheses. The first category of explanations hypothesize that conversion forcing calls of convertible securities reveal negative information about the firm's cash flows or prospects for stockholders. Calling convertible bonds may result in lost tax shields that reduce cash flow (Mikkelson 1981, 1985). Jensen (1986) predicts that calls may increase the agency problem of free cash flow since conversion-forcing calls replace fixed claims (preferred dividends or interest payments) with variable cash flows (common dividends). Harris and Raviv 1985 and Constantinides and Grundy 1987 offer an information-signaling rationale where calls reveal managers' pessimistic expectations concerning the future stock price or dividends of their firm. The negative stock price reaction to calls could also be explained by a wealth transfer from shareholders to bondholders (Mikkelson 1981). ${ }^{2}$

The second category hypothesizes that the negative stock price reaction to calls is due to short-term liquidity constraints (Mazzeo and Moore 1992). Some convertible security holders may dislike having the newly converted common shares in their portfolios thus conversion forcing calls may result in a temporary imbalance in supply and demand for shares. Anticipating increased selling pressure, dealers lower bid and ask quotes to attract buyers and deter sellers when conversion forcing calls are announced. After the temporary imbalance in supply and demand disappears, stock prices rebound to the pre-call announcement level. Thus Mazzeo and Moore (1992) argue that the down pricing around convertible calls is a temporary liquidity effect unrelated to any information about the firms' prospects. Interestingly, the first (negative information) hypothesis is not mutually exclusive of the second

Readers with questions or comments should contact the authors via email. 
(liquidity effect) hypothesis. The observed stock price behavior following conversion-forcing calls may be driven by an information event (which could include signaling) that is exacerbated by liquidity problems.

Several studies provide evidence for the above hypotheses. Ofer and Natarajan (1987) find that conversionforcing bond calls are associated with a decline in post-call earnings and negative cumulative abnormal returns in the post-call period suggestive of an information effect. However, Campbell, Ederington, and Vankudre (1991) argue that the negative post-call abnormal returns and earnings changes found by Ofer and Natarajan (1987) are biased due to the parameter estimation periods used in their study. Campbell, Ederington, and Vankudre (1991) find insignificant post-call cumulative abnormal returns when post-period parameter estimations are used. Asquith (1992, 1995) examines convertible bond call policy through time and shows that most bond calls are not delayed. Asquith argues against any information effect for bond calls since he shows that calls are not delayed. Byrd and Moore (1996) show that analysts revise upward their earnings estimates of firms making calls also arguing against an adverse information effect. Thus the overall results are mixed as to whether the negative stock price wealth effect of conversion-forcing calls is the result of negative information or is due to a short-term price-pressure effect.

The remainder of this paper is organized as follows. Section II offers insider-trading hypotheses for convertible calls while Section III describes the data and methodology. Results are reported in Section IV and a summary of the study is contained in Section V.

\section{Insider Trading Hypotheses}

If calls are associated with an adverse change in managerial expectations about the firm's cash flow or prospects for stockholders (as predicted by information-signaling models and intrafirm wealth transfers), then managers are expected to alter the pattern of investment in their firm's stock. Managers are expected to have unusually low levels of purchases and/or unexpectedly high levels of sales around call announcements.

In contrast, if the negative call-induced share price response is largely a short-term liquidity effect as offered by Mazzeo and Moore (1992), then managers should have little incentive to change the pattern of investment in their firm's stock. Indeed, managers might even choose to increase their purchases immediately after the call to take advantage of the temporarily low share prices that may result from short-term liquidity-based selling.

However, even if calls do indicate negative information about the firm's prospects, managers may not necessarily alter their trading behavior due to disincentives to trade on their personal account. These disincentives take the form of potential legal sanctions from the Securities and Exchange Commission as well as potential for diminished human capital from the adverse reputation effects associated with insider trading scandals. ${ }^{3}$ When managers do act on negative inside information, decreased purchase transactions may be preferable to increased sale transactions. That is, increased sales on private account are transactions that must be reported to the S.E.C. and may lead to increased public scrutiny. In contrast, managers' decisions to reduce purchases on private account is not a monitored action.

The threat of legal action may also impact the timing of managers' trades around call announcements. Specifically, managers who plan to sell their shares because of a downward revision in their beliefs regarding firm prospects may have an incentive to increase selling after (rather than before) the call announcement. Managers may wait until after the call announcement to sell shares to avoid the appearance of dumping the stock before an upcoming "bad news" event (e.g. a call). That is, managers can safely sell their stock without the threat of insider trading sanctions only after the call announcement. ${ }^{4}$

In summary, it seems unlikely that managers would alter their portfolio positions simply to take advantage of call-induced downpricing resulting from short-term liquidity effects. This is particularly true when potential legal sanctions are considered. Thus, any changes in managerial trading should be associated with longer-term factors such as (1) revisions in the firm's economic prospects, (2) higher agency costs as a result of increased free cash flow, (3) lower tax shields (for bond calls), or (4) permanent wealth transfers from equity holders to bond holders. 


\section{Data and Methodology}

\subsection{Convertible Call Sample}

Our initial sample consists of 111 convertible bond calls and 58 convertible preferred calls used by Mazzeo and Moore (1992). All of these convertible securities are in the money and thus force conversion from the convertible security into common stock. To be used in this study the observations must have complete insider trading information available in the S.E.C.'s monthly Official Summary of Security Transactions and Holdings, which is available from the U.S. National Archives and Records Service on the Ownership Reporting System Master File. Because January 1, 1975 is the earliest date that insider trading is recorded by the S.E.C. 78 convertible bond calls and 22 convertible preferred stock calls are eliminated from the sample. Our final sample contains 33 convertible bond calls and 36 convertible preferred calls announced between 1975 and 1987.

To corroborate that our sample is like those of prior studies we calculate the average announcement period abnormal stock returns for our convertible call sample and find negative wealth effects similar to prior studies. Using the method of Mikkelson and Partch (1988) and an equal-weighted market model with a post-announcement estimation period, the two-day average abnormal return for our sample of convertible bond calls is $-2.7 \%(\mathrm{Z}=-4.70)$, while our sample of convertible preferred calls produces a $-1.4 \%(\mathrm{Z}=-2.20)$ average abnormal return. Similar wealth effects are obtained using a pre-announcement estimation period and using a value-weighted market model.

\subsection{Insider Trading Measures}

Data reflecting insider-trading activity has been shown to be relatively infrequent, non-normally distributed, and related both to economy-wide market movements (Seyhun 1988) and to firm size (Seyhun 1986). To control for market-wide movements and firm size effects, we compare trading by calling firms' managers to that of managers from a matched sample of comparison firms. We divide our call sample into the deciles used by CRSP based on market value of equity and then randomly match eight comparison firms from the same CRSP market value of equity decile. $^{5}$ Therefore, our analyses involve 69 call firms and an accompanying matched sample of 552 comparison firms.

Data for all open market purchases and sales of 100 or more shares by officers and directors are collected from the Ownership Reporting System Master File for both call and comparison firms for two calendar years before and after the call announcements. This four-year period is divided into three subperiods before and after the call. We collect and report insider-trading activity for a two-year period, a one-year period, and a six-month period before and after the call announcement.

The first measure of managerial trading is the frequency of purchase and sale transactions per period for calling firms and for comparison firms. The number of sales and purchases per period for the calling firms are compared with the number of sales and purchases for the comparison firms. A second insider trading measure aggregates insider-trading frequency within each firm and classifies them as either net buyers or net sellers. The percentage of the calling firms classified as net buyers (net sellers) is then compared to the percentage of comparison firms classified as net buyers (net sellers) for each of the periods. Since insider-trading measures are shown to be non-normally distributed, non-parametric statistical methods are used to test for differences in managerial trading behavior around calls.

\section{4. $\quad$ Empirical Results}

\subsection{Insider Purchase and Sales Transactions}

Table I describes the frequency of insider sale transactions and purchase transactions for the sample firms for each of the test intervals. A stratified randomization test as described by Noreen (1989) is used to measure the significance of cross-sectional differences and a Wilcoxon matched-pairs signed rank test is used to measure the significance of time-series differences.

In panel A, we report the average number of sale transactions for the call and comparison firms. The time- 
series evidence indicates that managers of call firms significantly increase sales activity after the call. Call firms approximately double their frequency of sales over time, from 6.8 sale transactions in the two-year period before the call to 12.1 sale transactions in the two years after the call. The one-year and six-month event periods exhibit similar time-series increases in sales frequency for call firms and all three-event period differences are significant at the .01 level with a two-tailed test. The comparison firms average about 9 sales per firm in each of the two-year pre- and post-intervals and show no increase in average sale transactions over time. Cross-sectionally, the average number of sale transactions of call firms is significantly greater than for comparison firms in the post call period. The differences between call and comparison firms in the six-month and one-year post-periods are significant at the .05 level using a two-tailed test. For example, call firms average 6.62 sale transactions in the one-year post period compared to 4.59 transactions for the comparison firms. Prior to the call announcements, the average sales frequency of call firms does not statistically differ from comparison firms.

Panel B reports the average number of purchase transactions for the call and comparison firms. The results are similar for call and comparison firms. Managers average between 4 and 5 purchase transactions per firm in the two year pre- and post-periods. The purchase frequency of call and comparison firms are also similar in the one-year and six-month intervals. None of the cross-sectional or time-series differences are statistically significant.

\subsection{Firms Designated as Net Buyers or Net Sellers}

An alternate method of measuring trading behavior categorizes firms as either net buyers or net sellers by comparing the frequency of purchase and sale transactions within each firm for each time period. Classifying firms this way avoids giving excessive weight to firms that have highly active managerial traders and produces a measure that broadly illustrates the prevalence of managerial trading across firms that make conversion-forcing calls. Table II presents the proportion of call and comparison firms classified as net sellers (Panel A) and net buyers (Panel B) for each of the test intervals. A stratified randomization test is used to measure the significance of cross-sectional differences and a McNemar's test is used to measure the significance of time-series differences. ${ }^{6}$

In Panel A, the proportion of call firms classified as net sellers in the two-year pre-call period is $34.8 \%$ increasing to $47.8 \%$ in the two-year period after the call. This time-series difference is significant at the .054 level with a one-tailed test. This upward trend over time in the proportion of call firms classified as net sellers also appears when comparing the one-year and six-month periods around the call announcement. In contrast, the comparison firms in the six-month pre- and post-periods show a significant time-series decrease in the proportion of firms categorized as net sellers. None of the cross-sectional differences appear statistically significant at conventional levels.

Panel B shows that $21.7 \%$ of call firms are classified as net buyers in the two-year period prior to the call while only $11.6 \%$ of call firms are net buyers in the two-year period after the call. The significance level of this timeseries difference is .026 using a one-tailed test. Call firms exhibit a similar time-series reduction in the proportion of net buyers when comparing the one-year periods before and after the call. The proportion of comparison firms categorized as net buyers ranges from about $19 \%$ to $24 \%$ and the test statistics indicate no change in the proportion of net buyers over time in any of the test periods. The cross-sectional results show that after the call, about half as many call firms $(11.6 \%)$ are categorized as net buyers versus comparison firms (21.4\%). The one-year post period crosssectional difference is statistically significant (.045 level) using a one-tailed test. Prior to the call, the proportion of net buyers for the comparison firms and the call firms is similar at about $20 \%$ and none of the cross-sectional differences approach statistical significance.

\section{Summary}

Our results reveal that when abnormal insider trading is measured by average trading frequency, managers of calling firms initiate a statistically significant greater number of sale transactions immediately following call announcements when compared to managers of a group of matched comparison firms. On average, managers of calling firms roughly double their rate of sale transactions after the call is made. An alternative measure of abnormal insider trading gives complementary results. When calling firms are classified as either net buyers or net sellers 
based on insiders' overall transaction frequency, the results indicate a statistically significant decline (rise) in the percentage of call firms categorized as net buyers (net sellers) around the call announcement. Overall, the percent of call firms classified as net buyers drops by about one-half after the call while the percent of call firms categorized as net sellers increases by about one-half after the call. The evidence shows that managers are reducing their ownership stakes contemporaneous with the decision to call in-the-money convertible securities. These insider trading results 
are consistent with calls signaling a downward revision in managers' expectations of their firms' long-term prospects.

\section{Suggestions for further research}

Extensions of this research might include a study of the connection between analysts' earnings revisions around calls and the insider trading that occurs around calls. Another possible extension could be an analysis of dividend changes around calls and the relation to insider trading around calls. Both of these potential extensions would look for a consistent information signal around convertible security calls.

\section{Endnotes}

1. Mikkelson $(1981,1985)$ documents a negative reaction to calls of convertible bonds. Mais, Moore and Rogers (1989) provide evidence that calls of convertible preferred stock have negative valuation effects. More recently, Cowan, Nayer and Singh (1992) and Mazzeo and Moore (1992) report similar results.

2. Fields, Mais, and Moore (1995) provide evidence that part of the negative common stock price reaction from convertible bond calls is explained by a wealth transfer to senior security holders.

3. Karpoff and Lee (1991) describe the potential S.E.C. sanctions.

4. See Seyhun (1990) for a thorough discussion concerning this point.

5. Market value of equity for the call firms is determined as of the end of odd-numbered years. The sample of call firms and utility firms were excluded from the comparison firm sample.

6. McNemar's test is a version of the sign test and is appropriate for testing differences in proportions from two matched-pair samples which are not independent.

\section{References}

1. Asquith, P., “Convertible debt: A dynamic test of call policy,” Unpublished manuscript, MIT, 1992.

2. $\quad$ Asquith, P., "Convertible bonds are not called late," Journal of Finance, Vol. 50, pp. 1275-1289, 1995.

3. Byrd, A., and W. Moore, "On the information content of calls of convertible securities," Journal of Business Vol. 46, pp. 89-101, 1995.

4. Campbell, C., Ederington, L. and P. Vankudre, "Tax shields, sample-selection bias, and the information content of conversion-forcing calls," Journal of Finance, Vol. 46, pp. 1291-1324, 1991.

5. Constantinides, G., and B. Grundy, "Call and conversion of convertible corporate bonds: Theory and evidence, Working paper," University of Chicago, 1987.

6. Cowan, A., Nayer, N., and A. Singh, "Underwriting calls of convertible securities: A note," Journal of Financial Economics, Vol. 31, pp. 269-278, 1992.

7. Fields, L., Mais, E., and Moore, W., "Conversion-forcing security calls: Wealth transfers revisited," International Review of Economics and Finance, Vol. 4, pp. 17-27, 1995.

8. Harris, M., and A. Raviv, "A sequential signaling model of convertible debt call policy," Journal of Finance, Vol. 40, pp. 1263-1281, 1985.

9. Hirshey, M., and J. Zaima, "Insider trading, ownership structure, and the market assessment of corporate sell-offs," Journal of Finance, Vol. 44, pp. 971-908, 1989.

10. Jensen, M., "Agency costs of free cash flow, corporate finance and takeovers," American Economic Review, Vol. 76, pp. 323-329, 1986.

11. John, J., and L. Lang, "Insider trading around dividend announcements: Theory and evidence," Journal of Finance, Vol. 46, pp. 1361-1389, 1991.

12. Karpoff, J., and D. Lee, "Insider trading before new issue announcements," Financial Management, Vol. 20, pp. 18-26, 1991.

13. Lee, D., W. Mikkelson, and M. Parch, "Managers' trading around stock repurchases," Journal of Finance, Vol. 47, pp. 1947-1961, 1992.

14. Mais, E., W. Moore, and R. Rogers, "A re-examination of the shareholder wealth effects of calls of convertible preferred stock," Journal of Finance, Vol. 44, pp. 1401-1410, 1989.

15. Mazzeo, M., and W. Moore, "Liquidity costs and stock price response to convertible security calls," Journal of Business, Vol. 65, pp. 353-369, 1992.

16. Mikkelson, W., "Convertible calls and security returns," Journal of Financial Economics, Vol. 9, pp. 237264, 1981. 
17. Mikkelson, W.,"Convertible calls and stock price declines," Financial Analysts Journal, Vol. 41, pp. 63-69, 1985.

18. Mikkelson, W. and M. Partch, "Withdrawn security offerings," Journal of Financial and Quantitative Analysis, Vol. 23, pp. 119-133, 1988.

19. Noreen, E., Computer Intensive Methods for Testing Hypotheses: An Introduction, (John Wiley \& Sons., New York), 1989.

20. Ofer, A., and A. Natarajan, "Convertible call policies: An empirical analysis of an information signaling hypothesis," Journal of Financial Economics, Vol. 19, pp. 91-108, 1987.

21. Penman, S., "Insider trading and the dissemination of firms' forecast information," Journal of Business, Vol. 55, pp. 479-504, 1982.

22. Seyhun, H., "Insiders' profits, costs of trading, and market efficiency," Journal of Financial Economics, Vol. 16, pp. 189-212, 1986.

23. Seyhun, H., "The information content of aggregate insider trading," Journal of Business, Vol. 61, pp. 1-24, 1988.

24. Seyhun, H., "Do bidder managers knowingly pay too much for the target firms?" Journal of Business, Vol. 63, pp. 439-464, 1990.

25. Seyhun, H., and M. Bradley, "Corporate bankruptcy and insider trading," Journal of Business, Vol. 70, pp. 189-216, 1997. 